\title{
Contribution of Advanced Regeneration of Pinus radiata D. Don. to Transpiration by a Fragment of Native Forest in Central Chile Is out of Proportion with the Contribution to Sapwood Area
}

\author{
Don A. White ${ }^{1,2,3, *(\mathbb{D})}$, Richard P. Silberstein $4,5\left(\mathbb{C}\right.$, Francisco Balocchi-Contreras ${ }^{6,7} \oplus^{\circ}$, \\ Juan Jose Quiroga ${ }^{6}$ and Pablo Ramírez de Arellano ${ }^{6}$ \\ 1 Whitegum Forest and Natural resources, PO Box 3269, Midland, WA 6056, Australia \\ School of Veterinary and Life Sciences, Murdoch University, Murdoch, WA 6150, Australia \\ ARC Training Centre for Forest Value, University of Tasmania, Hobart, Tas. 7001, Australia \\ 4 Hydrological and Environmental Scientific Solutions, PO Box 237, West Perth, WA 6872, Australia; \\ richard.silberstein@hydroenviro.com.au \\ 5 Centre for Ecosystem Management, School of Science, Edith Cowan University, Joondalup, \\ WA 6027, Australia \\ 6 Bioforest SA, km 15 Camino a Coronel, Coronel 416000, Chile; Francisco.Balocchi@arauco.com (F.B.-C.); \\ Juan.Quiroga@arauco.com (J.J.Q.); Pablo.Ramirez@arauco.com (P.R.d.A.) \\ 7 Department of Water Resources, Universidad de Concepción, Chillán 3812120, Chile \\ * Correspondence: whitegumfnrm@gmail.com; Tel.: +61-451-046-613
}

Received: 15 December 2019; Accepted: 5 February 2020; Published: 7 February 2020

check for updates

\begin{abstract}
The transpiration of Nothofagus glauca (Phil.) Krasser and advanced Pinus radiata D. Don. regeneration was measured in a fragment of native $N$. glauca forest. Over the eight months of this study, $P$. radiata contributed approximately $60 \%$ of the total stand transpiration. This was out of proportion with the approximately $34 \%$ of the stand sapwood area contributed by $P$. radiata. This was due to the significantly greater sap flux density of the $P$. radiata compared to the $N$. glauca between May and October. Though the results are from a small study conducted as part of a larger experiment, it is argued that they suggest that invasion by $P$. radiata may substantially increase the risk from climate change to reserves of $N$. glauca forest in the Maule region of central Chile. In some reserves of N. glauca forest, Forestal Arauco S.A. manually removed P. radiata that regenerated after the wildfire of January 2017. This was a costly operation and there is a need for indices to assess competition. The ratio of sapwood area to leaf area is suggested as a potential index for assessing competition to identify stands at risk.
\end{abstract}

Keywords: Nothofagus glauca; sap flux density; competition; water-limited; invasive; weed; wildfire

\section{Introduction}

In the part of the coastal range of central Chile between the cities of Concepción and Santiago, the native forests are of type Roble-Hualo in which the deciduous Roble (Nothofagus obliqua (Mirb.) Oerst.) and Hualo (N. glauca (Phil.) Krasser) are the main species, especially on ridges and upper slopes of the range. This forest type has been described as vulnerable [1] due mainly to fragmentation. Existing reserves of this forest type have high conservation value.

There is a perception in Chile that the Pinus radiata D. Don. plantations were the primary cause of this fragmentation. Although some small areas of Roble-Hualo forest type were cleared to establish plantations of $P$. radiata, most of the forest was cleared for agriculture and the establishment of wheat 
and pastures. The forests were also selectively logged until the late 1980s for wood and to produce charcoal [2]. On the shallow soils and steep slopes of the coastal range, agriculture was largely a failure and after decades of declining productivity and soil losses, much of this agricultural land, which was originally native forest, was planted to Pinus radiata [3,4].

Whatever the cause, the result is many small fragments of $N$. glauca and N. obliqua forests that are surrounded by P. radiata plantations. The authors of [5] concluded that invasion by the shade intolerant $P$. radiata occurred mostly at the edge of these reserves but advised ongoing monitoring of this situation, particularly after any major disturbance. In January of 2017, large wildfires burned more than 550,000 of mostly forested land in the coastal range in an area that overlaps almost entirely the natural range of Roble and Hualo. Of the total burned area, 223,605 hectares were plantations of P. radiata, Eucalyptus globulus Labill. or E. nitens Maiden (Deane and Maiden) and 60,995 ha were native forest, a lot of which was either N. obliqua or N. glauca [6].

The shallow soil, seasonally dry Mediterranean climate type and the inherent fertility of the soils combine to make water the most important limit to productivity in the Itata and Maule regions of the coastal range [7]. The recent fire, and the possibility of more serious invasion of N. glauca by a new generation of $P$. radiata seedlings, has elevated the existing need for an understanding of the nature of competition by $P$. radiata for water resources in mixtures with $N$. glauca. Post-fire invasion by P. radiata has the potential to change the water balance of these natural forests and increase pressure on these already vulnerable forests. Forestal Arauco S.A., the largest plantation grower in the region, manually removed all of the post-fire $P$. radiata regeneration from at least one reserve but this is a costly operation. It is therefore important to quantify competition of $P$. radiata for water when it occurs as a weed within the native Roble-Hualo forests to assist forest managers to quantify the net benefits of intervening to manage invasions.

The aim of this research was to examine the relative consumption of water by naturally occurring and invasive exotic tree species in a region with a major plantation industry and subject to a Mediterranean climate. This paper reports concurrent measurements of transpiration in a mixed stand of $N$. glauca and advanced P. radiata regeneration. It tests the null hypothesis that water use per unit sapwood area is the same for N. glauca and P. radiata.

\section{Materials and Methods}

\subsection{Site Description}

The data reported in this study were measured within an N. glauca forest in which there were a number of 21- to 25-year old $P$. radiata trees. The area was not planted to $P$. radiata because it was too steep but is surrounded by a $P$. radiata plantation. The stand is on a South-East facing slope about $20 \mathrm{~km}$ East of the city of Constitución in the coastal range of central Chile. This study site is in the Mediterranean climate zone of central Chile and the rainfall is strongly winter dominant [8]; average annual rainfall from 2009 to 2019 was $950 \mathrm{~mm}$ [9].

The soil is very shallow with a clay loam texture and varies in depth from $0 \mathrm{~cm}$ to a maximum of $100 \mathrm{~cm}$. Even in the surface, the soil is mixed with fragments of the local rocks. These and the rocks the soil overlies are of the Dollimo Complex of the western coastal range that was described in detail by [10]. The rocks of the region are a mix of albite schists, greenschist derived from metamorphism of oceanic tholeiitic basalts, iron and manganese rich metachaerts, serpentinites with occasional marble lenses.

In May of 2016, a circular plot with an area of $400 \mathrm{~m}^{2}$ was established within this isolated fragment of N. glauca forest.

\subsection{Rainfall Measurements}

Measurements of rainfall were made at the township of Forel, about $5 \mathrm{~km}$ south-east of the site, using an automatic weather station (Weather Master 2000, Environdata-Warwick, Queensland, Australia) and using an RG12 tipping bucket rain gauge (Environdata-Warwick, Queensland, 
Australia) located in a clearing immediately adjacent to the top of the catchment. A correlation between rainfall measured with these gauges and with measurements made by the Chilean Dirección General de Aguas (DGA) at Forel was used to estimate rainfall at the site prior to the installation of the weather station and rain gauge.

\subsection{Stand Characteristics}

Prior to commencement of the measurements of transpiration, the diameter of all trees was measured together with the height of five individuals of each species. The basal area of each tree was calculated as well as the total basal area of each species. This study was part of a larger project in which a relationship between sapwood area and basal area was developed for both species [9]. This relationship was used to calculate the sapwood area of all trees and to estimate the sapwood area index for both species.

\subsection{Selection of Trees for Transpiration}

Each of the two species (N. glauca and P. radiata) was divided into three size classes, each contributing one-third of total stand basal area. The trees from each species were ranked in order of increasing size and the cumulative basal area was calculated starting with the smallest tree. The median tree from each of the resultant size classes was selected for measurement of transpiration.

\subsection{Transpiration}

In May of 2016, heat ratio type sapflow sensors were installed in three individuals each of $P$. radiata and N. glauca. These trees were selected as described above from three size classes that contributed one-third of the stand basal area of the species.

In each tree, a single heat ratio type sapflow sensor (Environmental Sensing Systems, Melbourne, Australia) was installed. Each sensor consisted of a logger with battery and solar panel and two thermocouple and one heater probes. The thermocouple and heater probes were inserted in $2.1 \mathrm{~mm}$ holes which were made using a cordless power drill and a $3 \mathrm{~cm}$ deep steel drill guide to assist in generating parallel holes. The centres of the holes were separated by $6 \mathrm{~mm}$. A heater probe was installed in the central hole and a probe with a thermocouple was installed in each of the holes up and down the tree from the heater probe. The thickness of the bark was measured, and the probes were installed on the north facing side of the tree so that the thermocouples were situated $10 \mathrm{~mm}$ under the bark and in the sapwood.

A two second heat pulse was generated every thirty minutes and temperature was measured every second from just before the pulse to $120 \mathrm{~s}$ after the pulse. The change in temperature from before the pulse to after was measured between 60 and $120 \mathrm{~s}$ after the pulse and the mean change in temperature was recorded for the downstream $\left(\Delta T_{1}\right)$ and upstream $\left(\Delta T_{2}\right)$ probes. Heat pulse velocity $\left(v_{h}\right)$ in $\mathrm{cm} \mathrm{h}^{-1}$ was calculated after [11] as

$$
v_{h}=\frac{\kappa}{x} \ln \left(\frac{\Delta T_{1}}{\Delta T_{2}}\right) 3600
$$

where $k$ was the thermal diffusivity of the sapwood and $x$ was the nominal distance of $0.6 \mathrm{~cm}$ between the heater and the thermocouples. Initially $k$ was given a default value of $2.5 \times 10^{-3} \mathrm{~cm}^{2} \mathrm{~s}^{-1}$.

The actual thermal diffusivity of sapwood $\left(k^{\prime}\right)$ was calculated using the method described in [11]. The sap velocity corrected for diffusivity was then calculated as:

$$
v_{h, \text { diffusivity }}=\frac{\kappa_{\text {actual }}}{\kappa_{\text {default }}} v_{h}
$$

The actual separation between probes is rarely exactly $0.6 \mathrm{~cm}$. To correct for probe misalignment, the average sap velocity between midnight and 4 am was calculated. At this time of day, it was 
assumed that the real sap velocity was zero. The measured sap velocity in this time period $\left(v_{h, n i g h t}\right)$ was then subtracted from all of the values already adjusted for diffusivity $\left(v_{h \text {,diffusivity }}\right)$ to give a velocity corrected for probe misalignment $\left(v_{\text {h,alignment }}\right)$.

$$
v_{h, \text { alignment }}=v_{h, \text { diffusivity }}-v_{h, \text { night }}
$$

After [11], the wound correction factor $(\beta)$ was calculated as a function of the wound width $(w)$ using the following polynomial. This linear correction factor was then multiplied by the velocity already corrected for diffusivity and alignment to give a velocity also corrected for the effect of wounding.

$$
\begin{gathered}
\beta=7.06 w^{3}+6.47 w^{2}+0.54 w+1.53 \\
v_{h, w o u n d i n g}=\beta v_{h . a l i g n m e n t}
\end{gathered}
$$

Some correction must also be made for the fact that heat does not diffuse through wood and water at the same rate. The final sap velocity $\left(v_{s}, \mathrm{~cm} \mathrm{~h}^{-1}\right)$ or sap flux density $\left(\mathrm{cm}^{3}\right.$ sap per $\mathrm{cm}^{2}$ of sapwood per hr) of sap was calculated as:

$$
v_{s}=\frac{v_{h, \text { wounding }} \rho_{b}\left(C_{w}+m_{c} C_{s}\right)}{\rho_{s} C_{s}}
$$

where $\rho_{b}$ was the basic density of the wood, $c_{w}$ was the specific heat of water, $\mathrm{m}_{\mathrm{c}}$ was the volumetric moisture content, $c_{S}$ was the specific heat of sap and $\rho_{S}$ was the density of sap.

These properties of the sapwood were estimated from samples collected in November of 2016 (before the fire) and in March of 2019 (after the fire). These were calculated as described in or using values provided in [11].

\subsection{Stand Transpiration}

Sapwood area was calculated for each tree using simple linear relationships between tree basal area and sapwood area. These models were developed and described in [9]. The slope of these models is 0.52 for the N. glauca and 0.69 for the P. radiata. Stand sapwood area per species was calculated as the sum of the sapwood area of the individual trees and expressed on a per hectare basis $A_{\mathrm{s}}$. Stand transpiration $(\mathrm{T})$ was calculated separately for the two species as the product of the average sap flux density for the three trees $\left(v_{\mathrm{S}}\right)$ and the stand sapwood area $\left(A_{\mathrm{S}}\right)$.

\subsection{Data Analysis}

For each month between May and December of 2016, the average hourly and daily sap flux density $\left(v_{\mathrm{s}}\right)$ for the month was calculated. The difference between species was analysed using a paired t-test. The data were analysed this way because there is a lot of variation within the species due to the low velocities in the smallest trees in each species because they are suppressed, and their crowns are less irradiated than either of the other trees.

\section{Results}

\subsection{Weather Conditions}

Rainfall at the site was $697 \mathrm{~mm}$ in 2016, 27\% below the average from 2009 to 2018 of $951 \mathrm{~mm}$. Rainfall from May to December in 2016 was $551 \mathrm{~mm}, 299 \mathrm{~mm}$ less than the average between 2009 and 2018 of $850 \mathrm{~mm}$ for this 8-month period (Figure 1). The measurement period was the driest 8-month period since 2009 but was preceded by a wetter than average year in 2015 (1106 mm). 


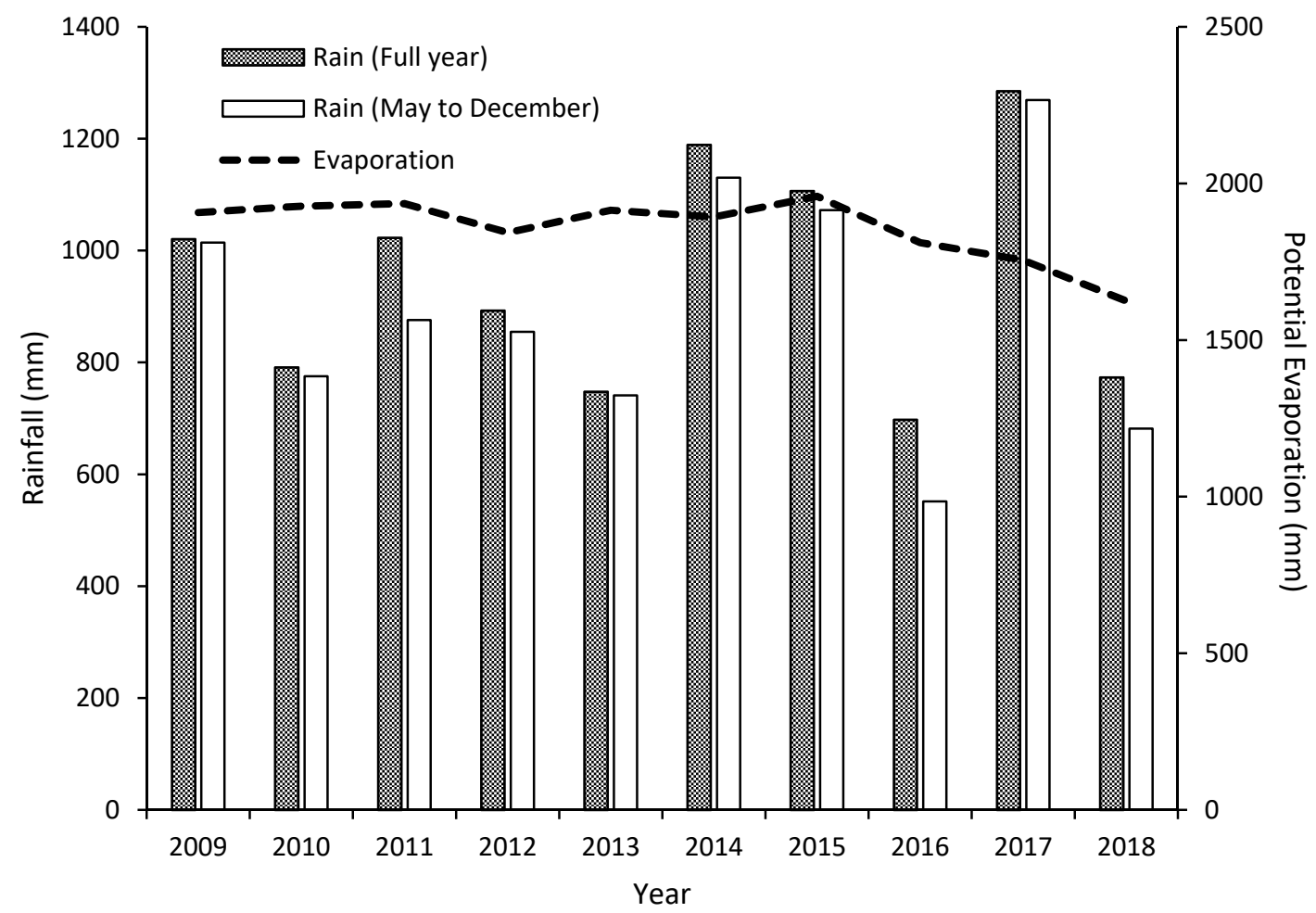

Figure 1. Annual rainfall, annual potential evaporation and rainfall from the beginning of May to the end of December for each year between 2009 and 2018. The measurement period and the full year of 2016 were the driest experienced at the site between 2009 and 2019.

\subsection{Tree Size and Numbers}

There were 38 trees in the plot or 950 stems per hectare. Twenty of these trees were N. glauca and 13 were $P$. radiata while the other five were native evergreen species. The median and average diameter and height of the $P$. radiata trees were slightly, but not significantly, less than that of the $N$. glauca in the stand. The $P$. radiata trees in this mixed stand had a mean height of $11.5 \mathrm{~m}, 2 \mathrm{~m}$ shorter than the $N$. glauca which has an average height of $13.6 \mathrm{~m}$. Similarly, the average diameter of the P. radiata was $11.2 \mathrm{~cm}$ and of the $N$. glauca trees was $13.8 \mathrm{~cm}$. The height to diameter ratio of approximately 100 was very similar for these two species in this mixed stand. The height and diameter distribution of both $N$. glauca and $P$. radiata were positively skewed (mean greater than median) due to the presence of a small number of large trees.

\subsection{Basal Area and Sapwood Area}

The slope of the relationship between sapwood area and basal area in this area was reported in [9] as 0.7 for $P$. radiata and 0.5 for $N$. glauca. This difference was statistically significant. Data from this mixed stand were included in that analysis and there was no evidence that the ratio of sapwood area to basal area was different for either species in this stand from that within pure stands of either species. Thus, these linear relationships between sapwood area (over bark) and basal area (under bark) were used to calculate the sapwood area of each $N$. glauca and $P$. radiata tree in the plot.

In both species, approximately $50 \%$ of the basal area and sapwood area in the stand was contributed by a small number of large trees (Figure 2). Pinus radiata contributed $34 \%$ (13) of the total of 38 trees in the plot. This translated to $27 \%$ of the total stand basal area of $37 \mathrm{~m}^{2} \mathrm{ha}^{-1}$ and $34 \%$ of the total stand sapwood area of $19.9 \mathrm{~m}^{2} \mathrm{ha}^{-1}$. 


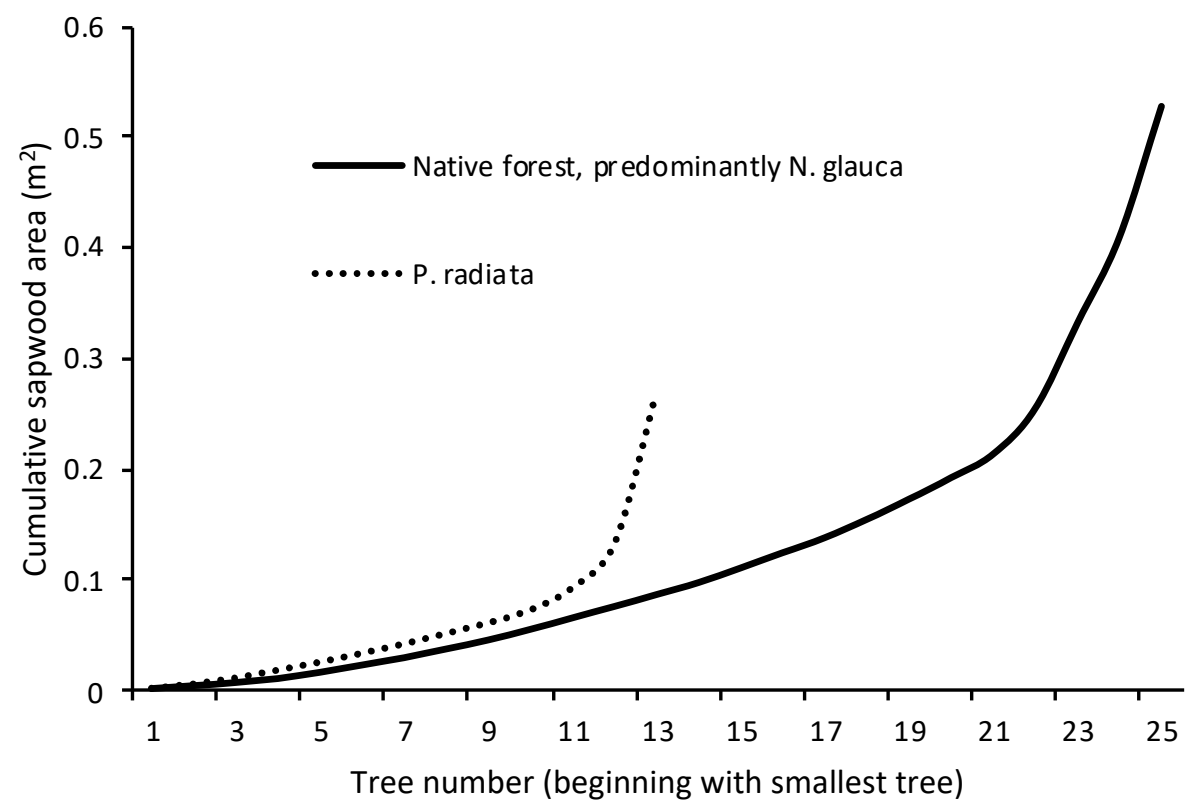

Figure 2. Cumulative sapwood area as a function of tree number, where the trees were sorted from smallest to largest within species. This shows that $P$. radiata contributed just over one-third of the total stand sapwood area and that in both species about half of the sapwood area was contributed by a small number of large trees.

\subsection{Tree and Stand Sap Flux Density}

Figure 3 shows the average daily sap flux density in volume $\left(\mathrm{cm}^{3}\right)$ of water per area of sapwood $\left(\mathrm{cm}^{2}\right)$ per day for each month between May and December of 2016 and for each of the three P. radiata and N. glauca trees measured. There was much larger variability between trees in the average daily sap flux density of $P$. radiata than was evident in $N$. glauca. In winter and early spring, the smallest $P$. radiata tree (which was supressed) had a much lower daily flux than the two larger trees. Later in spring, the sap flux density of the largest $P$. radiata tree decreased rapidly from $129 \mathrm{~cm}^{3} \mathrm{~cm}^{-2} \mathrm{day}^{-1}$ in September to $19 \mathrm{~cm}^{3} \mathrm{~cm}^{-2}$ day $^{-1}$ in December which was similar to the flux in the smallest tree. The sap flux density of all three $N$. glauca trees was close to zero in winter and increased to maximum values of between 20 and $70 \mathrm{~cm}^{3} \mathrm{~cm}^{-2}$ day $^{-1}$ in November and December (Figure 3).

Although there was a lot of variation amongst the $P$. radiata trees, the average sap flux density of P. radiata was significantly greater between May and October than in N. glauca (Figure 4). The difference was significant when the trees from the same size class of the two trees were treated as un-paired $(p<0.05)$ and highly significant when they were treated as paired $(p<0.001)$. In November and December, sap flux density did not differ significantly between the P. radiata and N. glauca (Figure 4). 


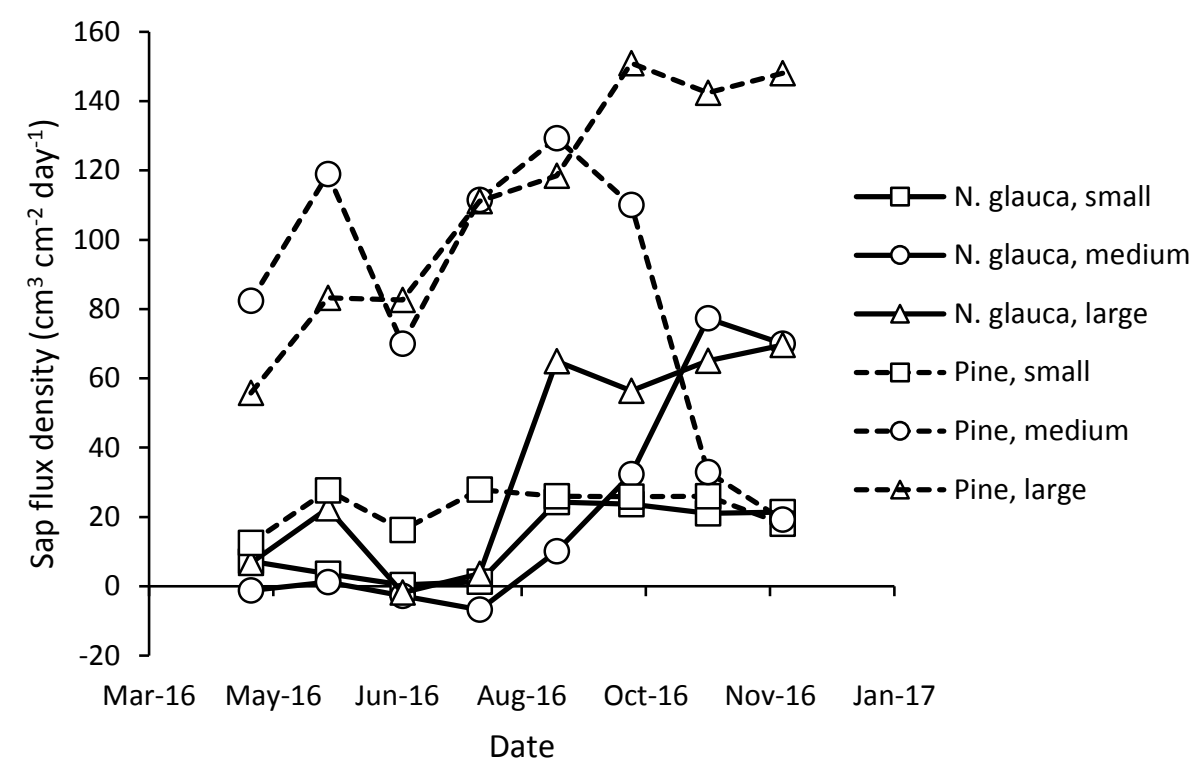

Figure 3. Time course of the average daily value of sap flux density for each month between May and December 2016. The measurements for each of the three N. glauca and P. radiata trees are shown separately.

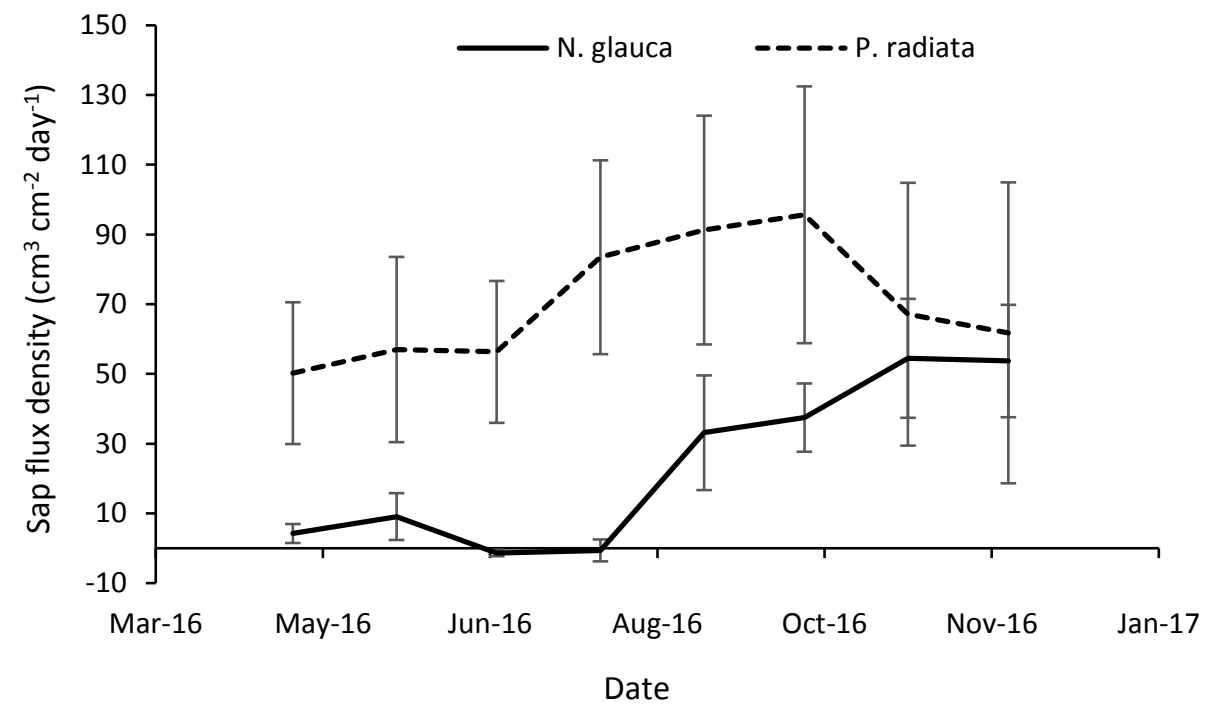

Figure 4. Time course of the average daily value of sap flux density for each month between May and December 2016 showing mean values and standard errors for $N$. glauca and P. radiata trees measured in the stand.

\subsection{Summary of Stand Characteristics and Transpiration}

The approximately one-third of the basal and sapwood area of the stand that was P. radiata contributed just under $60 \%$ of the total stand transpiration (Figure 5). The cumulative difference between the transpirations, expressed on a ground area basis, of P. radiata and N. glauca peaked by September of 2016. P. radiata competed very strongly for water in winter and early spring when the N. glauca was either without leaves or regrowing the canopy (Figure 6). 


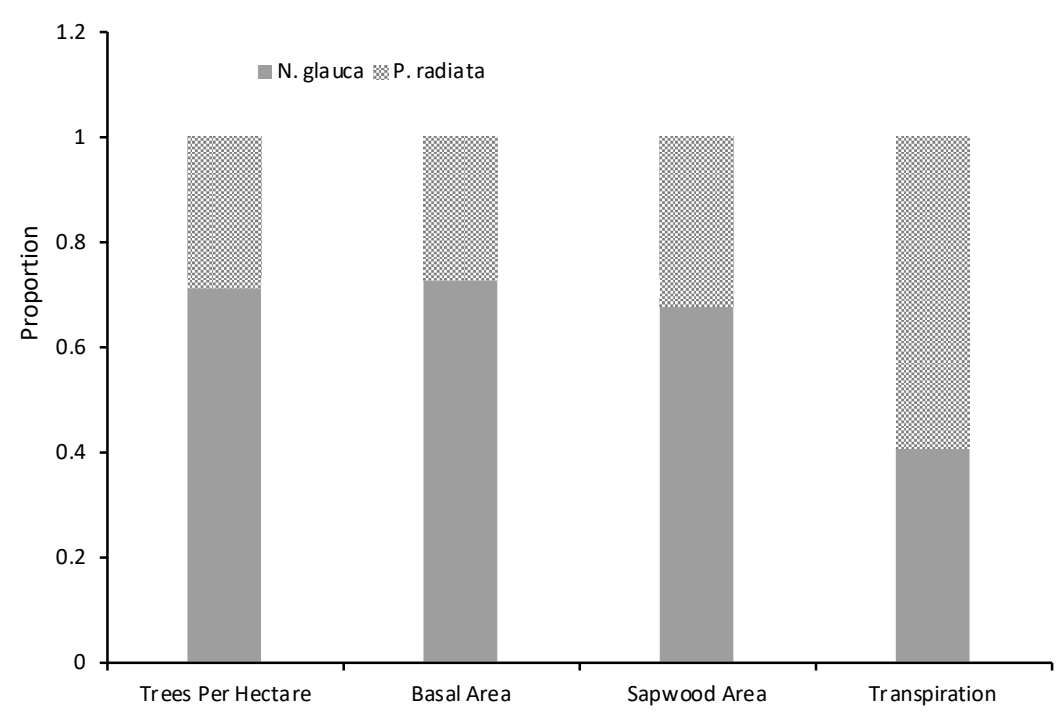

Figure 5. The proportion of the trees and stand basal area, sapwood area and transpiration contributed by $P$. radiata and N. glauca in this mixed stand.

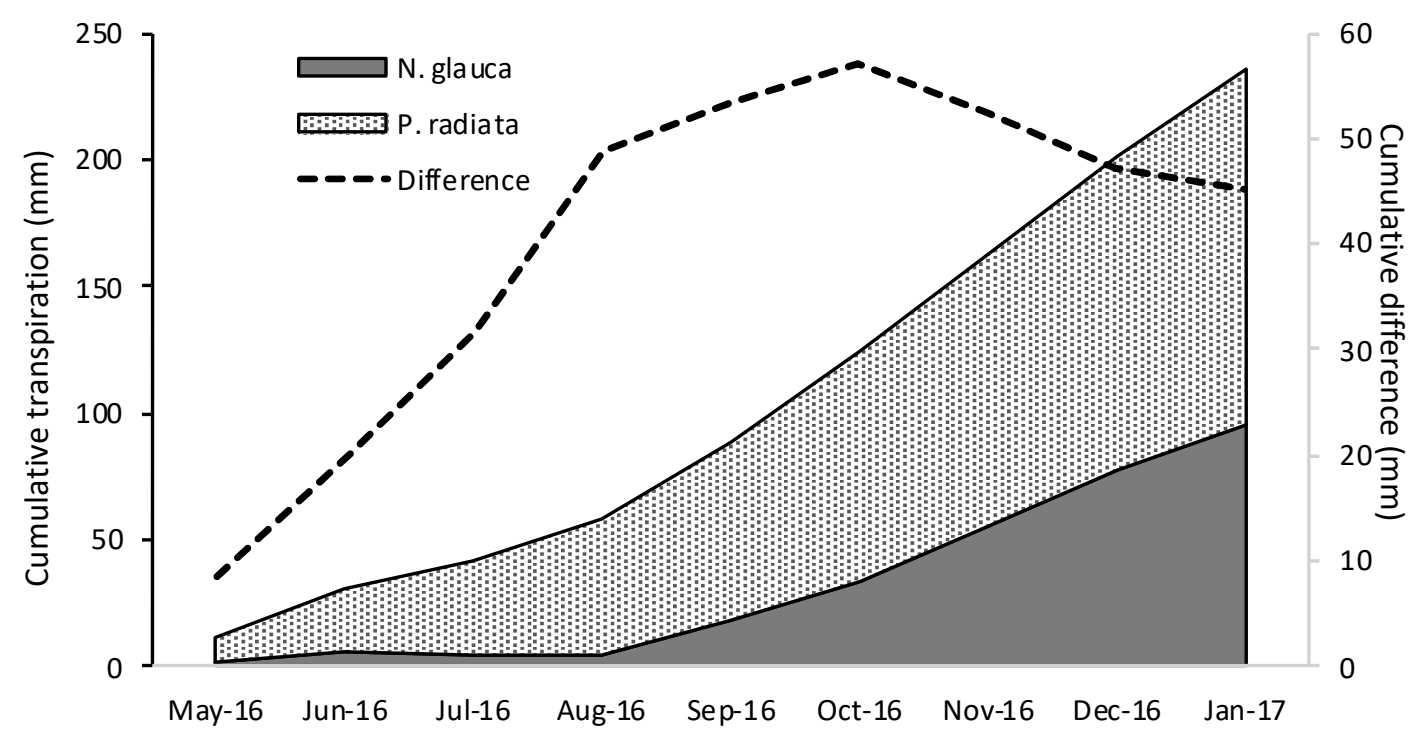

Figure 6. Cumulative transpiration on a ground area basis of both P. radiata and N. glauca in a mixed stand in central Chile. The cumulative difference between the P. radiata and N. glauca is also shown.

\section{Discussion}

This study quantified the contribution of advanced $P$. radiata regeneration that was between 20 and 25 years-old to the total transpiration of an $N$. glauca forest. The $P$. radiata comprised about one-third of the trees in the stand and a similar proportion of the basal and sapwood area of that forest. Owing to much greater sap flux density, the $P$. radiata trees in this forest, while only contributing one-third of the basal area, contributed nearly $60 \%$ of the total stand transpiration of $201 \mathrm{~mm}$. This is a very important result due to the vulnerability of fragments of the Roble-Hualo forests to invasion, especially after fire, from neighbouring P. radiata plantations [5]. It is therefore very important to consider the extent to which it can be argued that this behaviour will represent the effect of infestations more generally.

In this mixed forest, the P. radiata provided an evergreen presence in a mostly deciduous forest. The N. glauca in the plot were without leaves in June, July and August of 2016 [9]. The total cumulative difference between the transpiration of the P. radiata and $N$. glauca components of the forest was $49 \mathrm{~mm}$ at the end of August 2016 and $47 \mathrm{~mm}$ at the end of December (Figure 6. Thus, all of the difference 
between the P. radiata and N. glauca components of this forest occurred during the period when N. glauca was without leaves.

In pure stands, sclerophyllous native species such as N. glauca, have a more conservative, lower risk, water use strategy than commercial plantations. Plantations are grown to produce as much wood as possible from a given site while native systems have generally evolved to be more conservative [12,13]. In Mediterranean climates, regions such as in central Chile [9] and south western Australia [14], native forests use less water than plantations during spring and early summer. This is an important cause of their lower productivity than plantations and also for the generally lower water use efficiency of natural compared to planted forests. For a given canopy conductance, transpiration is more efficient during periods with lower air saturation deficit than during periods with drier air such as summer [15].

The deferral of spring water use by natural systems improves the chance of persistence in climates where extremely dry years are very likely to occur at least once in the life cycle of the forest [16]. The even seasonal pattern of water use of the N. glauca gives a more sustainable system at the expense of some productivity. In contrast, the spring dominant water use of plantations promotes productivity, but is associated with increased risk of drought mortality. The authors of [17] studied the relationship between the intensity of management and risk and noted that increased intensity of management in plantation systems can increase the risk of failure of plantations. At the same sites, [18] noted that increased intensity of management was associated with increased water use efficiency. It could be argued that the presence of $P$. radiata as an invasive in native forest, by biasing water use more towards spring, has potential to amplify the hazard to the Roble-Hualo forests of central Chile caused by reduced rainfall under climate change [19].

Invasive plants, such as the $P$. radiata in this study, are generally found to be more competitive for the most limiting resource (in this case water) than the local plants [20]. However, [20] noted that studies of local invasive plants were rare, thus conclusions about the competitiveness of invasive plants are biased. Invasive plants are often inherently competitive, a characteristic which may have become erroneously concluded to be a necessary association with invasiveness per se. Commercial plantation species are selected and subsequently bred to make them more competitive and efficient resource users. Thus, it is not surprising that such species, including Eucalyptus species [21], Acacia species and Pinus species [22] can invade local forest. Conversely, the productivity of both Pinus [23] and Eucalyptus [24] plantations can be compromised by infestations of woody weeds. The relative demand for resources of the invasive and other plants will determine the effect of the invasive on partitioning of resources within the system.

The primary cause of the observed difference of $47 \mathrm{~mm}$ between the total transpiration of the $P$. radiata and the $N$. glauca in this stand was increased sap flux density of the $P$. radiata during winter and spring. Sapwood area index has emerged in recent times as a useful index of actual water use [25] and indeed, as a deficit, of stream flow in forested systems [26]. The effect of P. radiata on the total water use of this forest was out of proportion with the fraction of stand basal or sapwood area. When competing with more conservative species, the commercial plantation species $P$. radiata may have a large impact on local water balance and will therefore likely increase the vulnerability of this forest to water shortage.

The competitiveness of invasive plants in water limited situations can be quantified by measuring sap flux density. This study indicates that this will be a better indicator of competitiveness than sapwood area index. However, this variable is prohibitively difficult and costly to measure operationally. There is therefore a need for more easily measured indices of competitiveness to guide and allocate investment in management and control. In a nearby reserve to this study site, Forestal Arauco S.A. manually removed all of the $P$. radiata that regenerated after the recent fires. In natural ecosystems, functional convergence in hydraulic traits has been observed so that the ratio of one trait to another is often common amongst the species [27-29]. Invasive species disturb this general equilibrium and may be detected by looking at relationships amongst characteristics. For example, we might expect a lower Huber value, ratio of sapwood to leaf area, in invasives than in locally adapted plants. The Huber value has been shown to be a good indicator of temporary disequilibria with site resources [30,31]. 
Forest fire is forecast to increase in frequency and intensity in this region, associated with a warming and drying climate. This is known to affect the structure of the local Roble-Hualo forest in the absence of woody invasives [32]. If, as suggested by [33], fire promotes invasion by P. radiata in the native forests of central Chile then to avoid further fragmentation and loss of these vulnerable forests $P$. radiata must be actively managed and reduced, especially in small fragments of Roble-Hualo forest. Forestal Arauco S.A. did manage invasion by P. radiata in key reserves. This is an expensive operation and there is therefore a need to develop methods to identify areas at greatest risk in these water-limited forests.

\section{Conclusions}

In this paper, we have examined the relative contributions to total water balance of naturally occurring Nothofagus and invasive exotic Pinus species in a region of Central Chile subject to a Mediterranean climate. This issue is of concern in regions where exotic species may disturb the water balance of naturally forested catchments.

$P$. radiata contributed about one-third of both the basal area and the sapwood area index at the study site. Owing to much greater sap flux density than the local N. glauca, the P. radiata contributed just under $60 \%$ of total transpiration, an amount that was out of proportion to the contribution to the sapwood area index. The null hypothesis, that the contribution to transpiration would be in proportion to the sapwood area, was rejected.

We suggest that the Huber value, ratio of sapwood to leaf area, should be investigated to test the utility for quantifying the competitiveness of $P$. radiata and other plantation species as invasives in the coastal range of central Chile.

Author Contributions: Conceptualization, D.A.W., R.P.S. and P.R.d.A.; methodology, D.A.W., R.P.S. and J.J.Q., F.B.-C.; investigation, all; writing-first draft D.A.W., editing by all. All authors have read and agreed to the published version of the manuscript.

Funding: This research received no external funding.

Acknowledgments: We would like to thank Forestal Arauco, SA in Chile for supporting this research through access to field sites, field assistance and the purchase of equipment. Many people at Forestal Arauco SA made important contributions but we would like in particular to thank Eduardo Rodriguez, the manager of Bioforest $\mathrm{SA}$, for his unstinting support of this work and of the project within which it was completed.

Conflicts of Interest: The authors declare no conflict of interest.

\section{References}

1. Wilson, K.; Newton, A.; Echeverría, C.; Weston, C.; Burgman, M. A vulnerability analysis of the temperate forests of south central Chile. Biol. Conserv. 2005, 122, 9-21. [CrossRef]

2. Fajardo, A.; Alaback, P. Effects of natural and human disturbances on the dynamics and spatial structure of Nothofagus glauca in south-central Chile. J. Biogeogr. 2005, 32, 1811-1825. [CrossRef]

3. Fuentes, E.R.; Hajek, E.R. Patterns of Landscape Modification in Relation to Agricultural Practice in Central Chile. Environ. Conserv. 1979, 6, 265-271. [CrossRef]

4. Altieri, M.A.; Rojas, A. Ecological Impacts of Chile's Neoliberal Policies, with Special Emphasis on Agroecosystems. Environ. Dev. Sustain. 1999, 1, 55-72. [CrossRef]

5. Bustamante, R.O.; Simonetti, J.A. Is Pinus radiata invading the native vegetation in central Chile? Demographic responses in a fragmented forest. Biol. Invasions 2005, 7, 243-249. [CrossRef]

6. De la Barrera, F.; Barraza, F.; Favier, P.; Ruiz, V.; Quense, J. Megafires in Chile 2017: Monitoring multiscale environmental impacts of burned ecosystems. Sci. Total Environ. 2018, 637-638, 1526-1536. [CrossRef]

7. Rubilar, R.; Blevins, L.; Toro, J.; Vita, A.; Muñoz, F. Early response of Pinus radiata plantations to weed control and fertilization on metamorphic soils of the Coastal Range, Maule Region, Chile. Bosque 2008, 29, 74-84. [CrossRef]

8. Armesto, J.; Arroyo, M.; Hinojosa, L. The Mediterranean Climate of Central Chile. In The Physical Geography of South America; Vleben, T., Young, K., Orme, A., Eds.; Oxford University Press: New York, NY, USA, 2007; pp. 184-199. 
9. White, D.A.; Balocchi-Contreras, F.; Silberstein, R.P.; Ramirez de Arellano, P. The effect of wildfire on the structure and water balance of a high conservation value Hualo (Nothofagus glauca (Phil.) Krasser.) forest in central Chile. For. Eco. Manage.. Under Review.

10. Gana, F.P.; Herve, A.F. Geologia Del Basamento Cristalino en la Cordillera de la Costa Entre Los Rios Mataquito y Maule, vii region. Rev. Geol. Chile 1982, 19-20, 39-56.

11. Burgess, S.S.O.; Adams, M.A.; Turner, N.C.; Beverly, C.R.; Ong, C.K.; Khan, A.A.H.; Bleby, T.M. An improved heat pulse method to measure low and reverse rates of sap flow in woody plants. Tree Physiol. 2001, 21, 589-598. [CrossRef]

12. Dunin, F.X.; MacKay, S.M. Evaporation of eucalypt and coniferous forest communities. In Proc. First Nat. Symp. Forest Hydrology Inst. of Engineers; Barton, ACT. Publ 82/6: Canberra, Australia, 1982; pp. 18-25.

13. White, D.A.; Beadle, C.L.; Battaglia, M.; Benyon, R.G.; Dunin, F.X.; Medhurst, J.L. A Physiological Basis for Management of Water Use by Tree Crops; Water and Salinity Issues in Agroforestry No 7; AFFA; JVAP; CSIRO FFP: Melbourne, Australia, 2001.

14. Gentilli. Climate of the Jarrah foest. In The Jarrah Forest-A Complex Mediterranean Ecosystem; Dell, J.B., Havel, J.J., Malacjuk, N., Eds.; Kluwer: Dordercht, The Netherlands, 1989; pp. 23-40.

15. Passioura, J. Increasing crop productivity when water is scarce-From breeding to field management. Agric. Water Manag. 2006, 80, 176-196. [CrossRef]

16. White, D.A.; Battaglia, M.; Macfarlane, C.; Mummery, D.; McGrath, J.F.; Beadle, C.L. Selecting species for recharge management in Mediterranean south western Australia-some ecophysiological considerations. Plant Soil 2003, 257, 283-293. [CrossRef]

17. White, D.A.; Crombie, D.S.; Kinal, J.; Battaglia, M.; McGrath, J.F.; Mendharn, D.S.; Walker, S.N. Managing productivity and drought risk in Eucalyptus globulus plantations in south-western Australia. For. Ecol. Manag. 2009, 259, 33-44. [CrossRef]

18. White, D.A.; McGrath, J.F.; Ryan, M.G.; Battaglia, M.; Mendham, D.S.; Kinal, J.; Downes, G.M.; Crombie, D.S.; Hunt, M.A. Managing for water-use efficient wood production in Eucalyptus globulus plantations. For. Ecol. Manag. 2014, 331, 272-280. [CrossRef]

19. Williams, C.J.R. Climate Change in Chile: An Analysis of State-of-the-Art Observations, Satellite-Derived Estimates and Climate Model Simulations. J. Earth Sci. Clim. Chang. 2017, 8. [CrossRef]

20. Vila, M.; Weiner, J. Are invasive plant species better competitors than native plant species? evidence from pair-wise experiments. OIKOS 2004, 105, 229-238. [CrossRef]

21. Forsyth, G.; Richardson, D.; Brown, P.; van Wilgen, B. A rapid assessment of the invasive status of Eucalyptus species in two South African provinces. S. Afr. J.Sci. 2004, 100, 75-77.

22. Rouget, M.; Richardson, D.; Nel, J.; van Wilgen, B. Commercially important trees as invasive aliens - towards spatially explicit risk assessment at a national scale. Biol. Invasions 2002, 4, 397-412. [CrossRef]

23. Watt, M.S.; Whitehead, D.; Mason, E.G.; Richardson, B.; Kimberley, M.O. The influence of weed competition for light and water on growth and dry matter partitioning of young Pinus radiata, at a dryland site. For. Ecol. Manag. 2003, 183, 363-376. [CrossRef]

24. Hunt, M.A.; Battaglia, M.; Davidson, N.J.; Unwin, G.L. Competition between plantation Eucalyptus nitens and Acacia dealbata weeds in northeastern Tasmania. For. Ecol. Manag. 2006, 233, 260-274. [CrossRef]

25. Roberts, S.; Barton-Johnson, R.; McLarin, M.; Read, S. Predicting the water use of Eucalyptus nitens plantation sites in Tasmania from inventory data, and incorporation of water use into a forest estate model. For. Ecol. Manag. 2015, 343, 110-122. [CrossRef]

26. Benyon, R.G.; Lane, P.N.J.; Jaskierniak, D.; Kuczera, G.; Haydon, S.R. Use of a forest sapwood area index to explain long-term variability in mean annual evapotranspiration and streamflow in moist eucalypt forests. Water Resour. Res. 2015, 51, 5318-5331. [CrossRef]

27. Bucci, S.J.; Goldstein, G.; Meinzer, F.C.; Scholz, F.G.; Franco, A.C.; Bustamante, M. Functional convergence in hydraulic architecture and water relations of tropical savanna trees: From leaf to whole plant. Tree Physiol. 2004, 24, 891-899. [CrossRef] [PubMed]

28. Meinzer, F.C. Functional convergence in plant responses to the environment. Oecologia 2003, 134, 1-11. [CrossRef] [PubMed]

29. Meinzer, F.C.; Clearwater, M.J.; Goldstein, G. Water transport in trees: Current perspectives, new insights and some controversies. Environ. Exp. Bot. 2001, 45, 239-262. [CrossRef] 
30. Carter, J.L.; White, D.A. Plasticity in the Huber value contributes to homeostasis in leaf water relations of a mallee Eucalypt with variation to groundwater depth. Tree Physiol. 2009, 29, 1407-1418. [CrossRef]

31. Fan, D.-Y.; Jie, S.-L.; Liu, C.-C.; Zhang, X.-Y.; Xu, X.-W.; Zhang, S.-R.; Xie, Z.-Q. The trade-off between safety and efficiency in hydraulic architecture in 31 woody species in a karst area. Tree Physiol. 2011, 31, 865-877. [CrossRef]

32. Pollmann, W.; Veblen, T.T. Nothofagus Regeneration Dynamics in South-Central Chile: A Test of a General Model. Ecol. Monogr. 2004, 74, 615-634. [CrossRef]

33. Armesto, J.; Bustamante-Sánchez, M.; Díaz, M.; González, M.; Holz, A.; Nuñez-Avila, M.; Smith-Ramírez, C. Fire Disturbance Regimes, Ecosystem Recovery and Restoration Strategies in Mediterranean and Temperate Regions of Chile. In Fire Effects on Soils and Restoration Strategies; Pontificia Universidad Católica de Chile: Santiago, Chile, 2009; pp. 537-567. [CrossRef]

C 2020 by the authors. Licensee MDPI, Basel, Switzerland. This article is an open access article distributed under the terms and conditions of the Creative Commons Attribution (CC BY) license (http://creativecommons.org/licenses/by/4.0/). 